\title{
Occurrence of Resistance-Breaking Isolates of Rice yellow mottle virus in West and Central Africa
}

Oumar Traoré, Institut de l'Environnement et de Recherches Agricoles (INERA) 01 BP 476 Ouagadougou 01, Burkina Faso; Agnès Pinel and Eugénie Hébrard, Institut de Recherche pour le Développement, IRD, 64501, 34394 Montpellier cedex 5, France; Mawena Y. Dieudonné Gumedzoé, Ecole Supérieure d'Agronomie, Université de Lomé, BP 1515 Lomé, Togo; Denis Fargette, Institut de Recherche pour le Développement, IRD, 64501, 34394 Montpellier cedex 5, France; Alfred S. Traoré, UFR/SVT, Département de Biochimie-Microbiologie, BP 7021 Ouagadougou, Burkina Faso; and Gnissa Konaté, Institut de l'Environnement et de Recherches Agricoles (INERA) 01 BP 476 Ouagadougou 01, Burkina Faso

\begin{abstract}
Traoré, O., Pinel, A., Hébrard, E., Gumedzoé, M. Y. D., Fargette, D., Traoré, A. S., and Konaté, G. 2006. Occurrence of resistance-breaking isolates of Rice yellow mottle virus in West and Central Africa. Plant Dis. 90:259-263.

Rice yellow mottle virus (RYMV) is the most important rice-infecting virus in Africa. Highly resistant rice (Oryza spp.) cultivars Gigante and Tog5681 were challenged with virus isolates from five countries of the west and central African Sudano-savannah zone in order to investigate the occurrence and prevalence of resistance-breaking (RB) isolates. High resistance was overcome by $38.6 \%$ of the isolates. RB isolates could be divided into three main pathogenic groups. Isolates of the first group (17.5\%) and of the second group (16.4\%) were able to break down the resistance of Gigante only and of Tog5681 only, respectively. Resistance in both cultivars was overcome simultaneously by isolates of the third group (4.7\%). In each group, some isolates induced symptoms, whereas plant infection by others was evidenced only by serological tests. $\mathrm{RB}$ isolates occurred in all five countries with varying frequencies (19 to $57 \%$ ). The wide geographical distribution and high frequencies of RB isolates represent a high risk for the durability of resistance to RYMV in the Sudano-savannah zone.
\end{abstract}

Additional keyword: Sobemovirus

Rice (Oryza spp.) is a staple cereal crop in most countries of Africa. The production of paddy rice was estimated at more than 12 million metric tons for SubSaharan Africa in 2003 (Food and Agriculture Organization of the United Nations (FAO), www.fao.org). Yet, rice production does not fulfill the needs for feeding the growing population. Substantial quantities of rice are imported yearly (about 2 million metric tons of husked rice in 2002). Despite a continuous increase in rice area under cultivation, yields remained very low (1 to $3 \mathrm{t} / \mathrm{ha}$ ). Rice production in the African continent is seriously threatened by rice yellow mottle, a disease caused by Rice yellow mottle virus (RYMV, genus Sobemovirus [16]). RYMV was first reported in Kenya in the 1960s (4) and is now found in most rice growing areas of Africa, but not outside the continent $(1,16,27)$. Under natural conditions,

Corresponding author: Oumar Traoré

E-mail: traoreo@liptinfor.bf

Accepted for publication 10 August 2005.

DOI: 10.1094/PD-90-0259

(C) 2006 The American Phytopathological Society
RYMV is transmitted by beetles (5), mammals like cows, rats, or donkeys, and also mechanically through the action of wind $(24,25)$. RYMV epidemiology is complex, and attempts to control the disease have been directed mainly to breeding for resistance. Most rice cultivars, especially those of the Oryza sativa indica species, are susceptible to RYMV, and they may suffer from 25 to $100 \%$ yield losses $(1,3,21)$. However, the rice (O. sativa) cultivar Gigante and the African rice $(O$. glaberrima) cultivars Tog5681, Tog5672, and Tog5675 are highly resistant to RYMV $(7,18)$. Negligible yield losses were reported when resistant cultivars Gigante and Tog5672 were challenged with 15 RYMV isolates in field trials (21). High resistance behaves as a monogenic recessive genetic trait and is associated with lack of symptom development and blockage of virus movement (19). To develop varieties with better resistance to RYMV, the high resistance sources were crossed with highyielding susceptible rice lines (29). However, it has been reported recently that some RYMV isolates were capable naturally (15) or after serial inoculations (9) of breaking down the high resistance of $\mathrm{Gi}$ gante and Tog5681. Therefore, if such resistance-breaking (RB) isolates were frequent in field conditions, this would undermine the stability of resistance to RYMV.

In this paper, we report on the occurrence and prevalence of $\mathrm{RB}$ isolates of RYMV in five West and Central African countries of the Sudano-savannah region. Pathological properties of these isolates were studied in the two highly resistant rice cultivars Gigante and Tog5681 which are being used currently as donors of resistance to RYMV and also, for comparison, in the susceptible rice cultivar BG 90-2.

\section{MATERIALS AND METHODS}

Virus sources and propagation. A total of 280 RYMV isolates from our virus collection were used in this study. They were collected in rice fields from three countries of West Africa (Burkina Faso, Mali, and Togo) and two of Central Africa (Cameroon and Chad). The area of isolate collection is part of the Sudano-savannah zone ( 7 to $15^{\circ}$ north latitude, $17^{\circ}$ west $24^{\circ}$ east longitude).

To get sufficient material, isolates collected from the field were mechanically inoculated and propagated in the susceptible cultivar BG90-2 before inoculation. Leaf samples were ground in $100 \mathrm{mM}$ phosphate buffer, $\mathrm{pH} 7.0(10 \mathrm{ml}$ per g leaf sample), using sterile mortars and pestles. Carborundum (600 mesh) was added to the extracts, which were subsequently rubbed onto leaves of 2-week-old seedlings. Leaves were collected from infected plants 14 days postinoculation and used as an inoculum source for resistance evaluation tests. No dosage effect of the inoculum was observed in our experiments, as virus accumulated to a similar extent in the susceptible control cultivar BG90-2 whatever the pathotype inoculated.

Evaluation of resistance to RYMV. Experiments were done in an insect-proof greenhouse at 25 to $30^{\circ} \mathrm{C}$ and 80 to $90 \%$ relative humidity. Seeds from the resistant rice cultivars Gigante and Tog5681 and the susceptible standard BG90-2 were sown in 5-liter pots. Mechanical inoculations were done on seedlings (15 plants per virus isolate) 2 weeks postgermination. Symptom appearance was monitored for 45 days 
after inoculation. Thereafter, disease severity was scored using a 1 (no symptoms) to 9 (severe symptoms) scale (14), and the last fully expanded leaf on each inoculated plant was collected. Because most infected BG90-2 plants started drying 3 weeks postinoculation, leaves were collected at 25 days postinoculation (dpi) for this cultivar. Leaves for the same isolate were pooled and assayed by serology for virus presence and titer.

Serological tests. Double antibody sandwich enzyme-linked immunosorbent assay (DAS-ELISA) was used to detect RYMV in leaf samples (6). A polyclonal antibody that reacts strongly and similarly with all the RYMV isolates of West and Central Africa was used as the coating antibody (20). The same antibody was coupled to alkaline phosphatase and used as conjugate. All buffer system and incubation times were as previously described (15). For detection of RYMV in the samples, analyses were done directly on extracts obtained after grinding the leaves (1 $\mathrm{g}$ in $10 \mathrm{ml}$ of buffer) and centrifugation at $8,000 \times g$ for $10 \mathrm{~min}$. For virus content comparison between samples, leaf extracts were subsequently diluted 10 and 100 times and assayed.

\section{RESULTS}

Symptom expression. Up to 46 isolates of the total set of 280 virus isolates in- duced clearly visible mottle symptoms after inoculation of the highly resistant rice cultivars Gigante or Tog5681. Analysis of variance of the time taken for symptom development indicated a significant cultivar effect $(F=232.6$, df $=2, P<0.001)$. On average, symptoms appeared 31 and 33 dpi, respectively. Symptoms appeared earlier in BG90-2 (7 dpi) than in Gigante and Tog5681. Symptoms were also induced in a shorter time interval in BG90-2 than in the resistant cultivars (6 to $10 \mathrm{dpi}$ versus 19 to $42 \mathrm{dpi}$ ). No significant difference was observed between Gigante and Tog5681 $(P>0.33)$. Symptom severity scores were high in BG90-2 (79). Lower scores (3 to 5) were recorded from the highly resistant cultivars, although symptoms were more discernible in Gigante than in Tog5681. Moreover, the proportion of infected plants of the highly resistant cultivars was relatively low. RYMV incidence was 6 to $20 \%$ in Gigante or $\operatorname{Tog} 5681$, whereas plants from the susceptible standard BG90-2 showed infection rates close or equal to $100 \%$.

The 46 virus isolates that induced symptoms in the highly resistant rice cultivars could be divided into three groups. Isolates of the first group (36 isolates) induced symptoms in Gigante only. In the second group of isolates (7 isolates), symptoms were induced in Tog5681 only. The $z$ test for difference of proportions (10) indicated

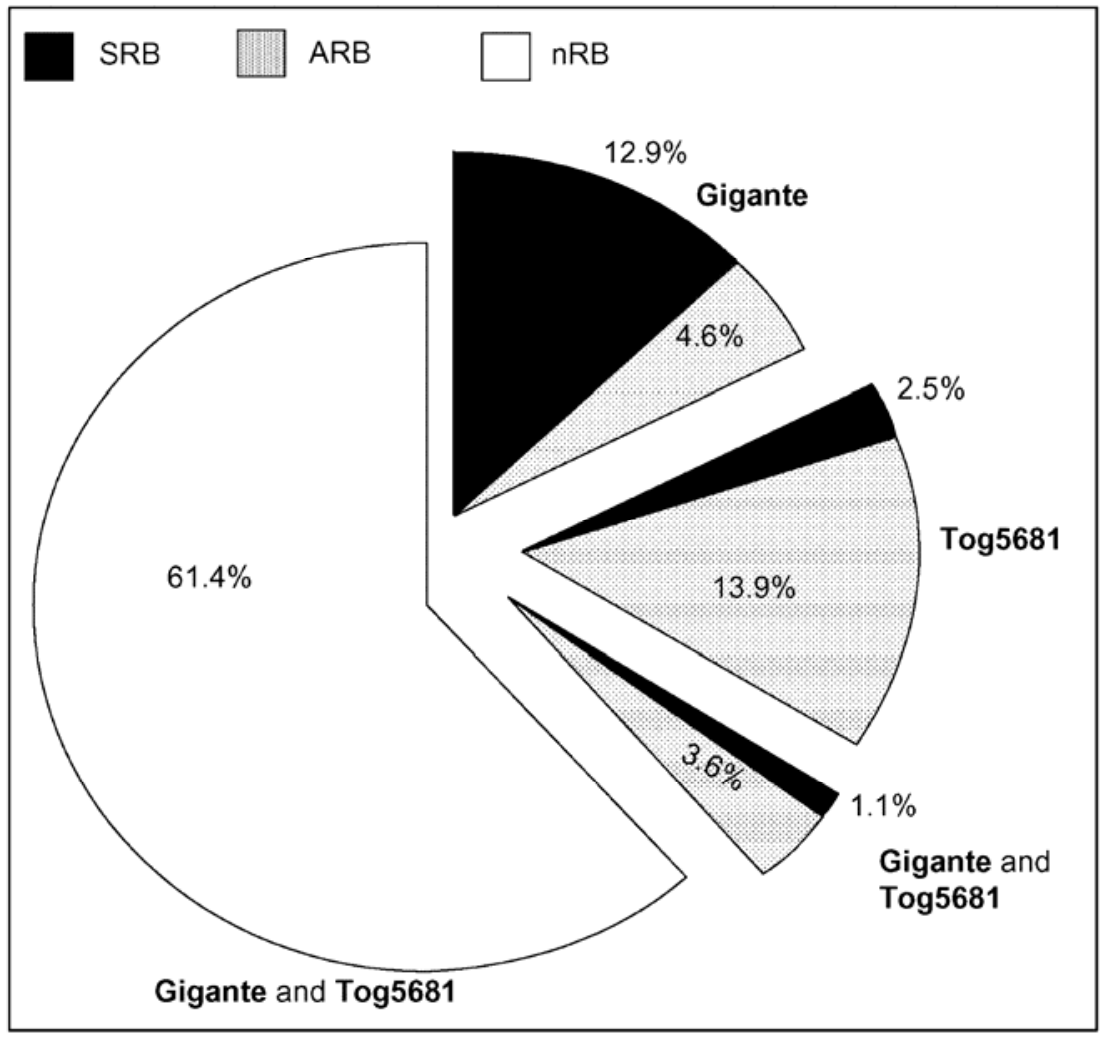

Fig. 1. Frequency of high resistance-breaking (RB) isolates of Rice yellow mottle virus (RYMV) in Sudano-savannah areas. Resistance was broken down in rice cultivars Gigante or Tog5681 singly or in both cultivars at a time with (SRB) and without (ARB) symptom induction. Non-resistance-breaking isolates (nRB) did not induce any infection in highly resistant rice cultivars as ascertained by enzymelinked immunosorbent assay and subsequent back-inoculations to the susceptible cultivar BG90-2. that the proportion of isolates in the first group $(78.3 \%)$ was significantly higher $(z$ $=5.85, P<0.01)$ than that of isolates in the second group $(15.2 \%)$. The last group (3 isolates) included isolates that induced symptoms in both Gigante and Tog5681.

RYMV detection in asymptomatic leaf samples. Of the 280 isolates tested, 234 did not induce obvious symptoms in the highly resistant cultivars. However, ELISA revealed the presence of the virus in asymptomatic plants inoculated with 62 of 234 isolates. Presence of the virus in these samples was confirmed by backinoculation tests to the standard susceptible cultivar BG90-2 (data not shown). Because ELISA-positive asymptomatic plants differed from healthy ones by their positive serological reaction only, symptom severity index was given a score of 1 . As for symptomatic infections, the 62 isolates that showed symptomless infections can be divided into three groups: (i) 13 isolates infecting Gigante alone, (ii) 39 isolates infecting Tog5681 alone, and (iii) 10 isolates infecting both cultivars simultaneously. Thus, the proportion of asymptomatic infections in Gigante was significantly lower than in Tog5681 $(z=4.55, P$ $<0.01)$.

No virus was detected by ELISA in plants inoculated with 172 of 234 RYMV isolates that did not induce any symptom in the rice cultivars Gigante and Tog5681. Altogether, the absence of any detectable virus multiplication and symptom expression indicated that those isolates were not capable of breaking down the high resistance of the two cultivars.

Prevalence of high RB isolates. Altogether, $38.6 \%$ of the whole set of 280 RYMV isolates were able to infect the highly resistant rice cultivars (Fig. 1). Consequently, these isolates were identified as the high RB isolates. Alternatively, the overall proportion of non-resistancebreaking isolates was $61.4 \%$. High RB isolates included isolates that induced either symptomatic $(16.5 \%)$ or asymptomatic $(22.1 \%)$ infections, respectively, referred to as symptomatic resistancebreaking isolates (SRB) and asymptomatic resistance-breaking isolates (ARB). In all, proportions of isolates able to break down the high resistance in Gigante and Tog5681 were similar. However, more SRB isolates (12.9\%) showed symptoms in Gigante compared to those $(2.5 \%)$ infecting Tog5681. Inversely, RB isolates showing symptomless infections were more frequent in Tog5681 than in Gigante. Simultaneous RB in Gigante and Tog5681 was observed with a low proportion of the isolates. Moreover, symptomatic infections in this case were three times less than asymptomatic ones.

Geographical distribution of RB isolates. High RB isolates were found in each country, but frequencies varied between countries (Fig. 2). The highest proportions 
were recorded in Burkina Faso (57.3\%) and Chad (50\%). Significantly lower proportions were observed in Cameroon (28.4\%), Mali (20.7\%), and Togo (19.1\%). On average, frequencies of RB isolates between West and Central African countries were similar $(z=1.167, P=0.27)$. However, the proportions of $\mathrm{RB}$ isolates that broke down the high resistance in Gigante or Tog5681 differed between the two regions (Fig. 3). The proportion of Central African RB isolates that broke down the resistance of Gigante was significantly higher than that of West African RB isolates $(z=3.41, P<0.001)$. Inversely, RB isolates that broke down the resistance of Tog5681 were less frequent in Central Africa than in West Africa $(z=3.58, P<0.001)$. Isolates that broke down the resistance in both Gigante and Tog5681 were found only in West Africa.

Virus content associated with RB. Virus titer was assessed in the systemically infected leaves of both symptomatically and asymptomatically infecting RB isolates. At 1:100 dilution, no virus could be detected by ELISA in some extracts (data not shown). Therefore, all extracts were tested at 1:10 dilution. Two-way analysis of variance of virus titer indicated significant effects of pathotype $(F=157.4$, df $=$ $1,36 ; P<0.001)$, cultivar $(F=215.6, \mathrm{df}=$ 2, 36; $P<0.001$ ), and pathotype-cultivar interactions $(F=21.0$, df $=2,36 ; P<$ $0.001)$. Virus titers in leaf extracts of the susceptible standard cultivar BG90-2 inoculated with SRB, ARB, or nonresistance-breaking isolates were similar (Fig. 4). By contrast, Gigante and Tog5681 plants inoculated with SRB isolates gave significantly higher virus titers than those inoculated with ARB isolates. In any case, virus titers were higher in BG90-2 plants. There was no significant difference in virus content in BG90-2 between plants inoculated by $\mathrm{RB}$ isolates breaking the resistance of Gigante and of Tog5681 (data not shown).

\section{DISCUSSION}

Most RYMV isolates (61\%) examined in this study did not induce any disease in rice cultivars Gigante and Tog5681. This is in line with earlier reports of absence of symptoms and lack of detectable virus multiplication after inoculation of Gigante and $\operatorname{Tog} 5681$, which were subsequently referred to as highly resistant cultivars $(13,15,18,19,21)$. However, in one instance, mild symptoms were observed on these resistant cultivars after inoculation with field isolates $(9,15)$. Our results show the characteristics, prevalence, and distribution of such isolates in the Sudanosavannah zone. Some of these isolates induced rather severe symptoms (score = 5). In other cases, symptoms were milder ( score $=3$ ) or only observed late on new growth sprouting from inoculated plants that remained asymptomatic even after the flowering stage (data not shown). Another type of isolate which multiplied in the highly resistant cultivars without inducing any symptom was found in the Sudanosavannah zone. Differences between ARB and $\mathrm{RB}$ isolates may reflect contrasting abilities to replicate in the resistant cultivars as virus content of $\mathrm{ARB}$ isolates was lower than that of RB isolates but similar in susceptible cultivars. In some instances, serial inoculations of ARB isolates resulted in SRB isolates with symptom development (9). It should be tested whether this ability is shared by other ARB isolates in order to learn whether an increasing proportion of SRB isolates, the most damag- ing ones, is expected after resistance deployment in the fields.

Altogether, RYMV isolates from the Sudano-savannah zone induce disease in highly resistant rice cultivars with a relatively wide range symptom severities (scores 1 to 5), but never as severe as in the susceptible cultivar BG90-2 (scores of 7 to 9 ).

In some pathogenic aspects, cultivars Gigante and Tog5681 had similar behaviors. In both cultivars, symptoms appeared late or did not appear at all. Disease incidence, severity and virus titers were always significantly lower than in BG90-2. All these shared features may be associated with the fact that the high resistance

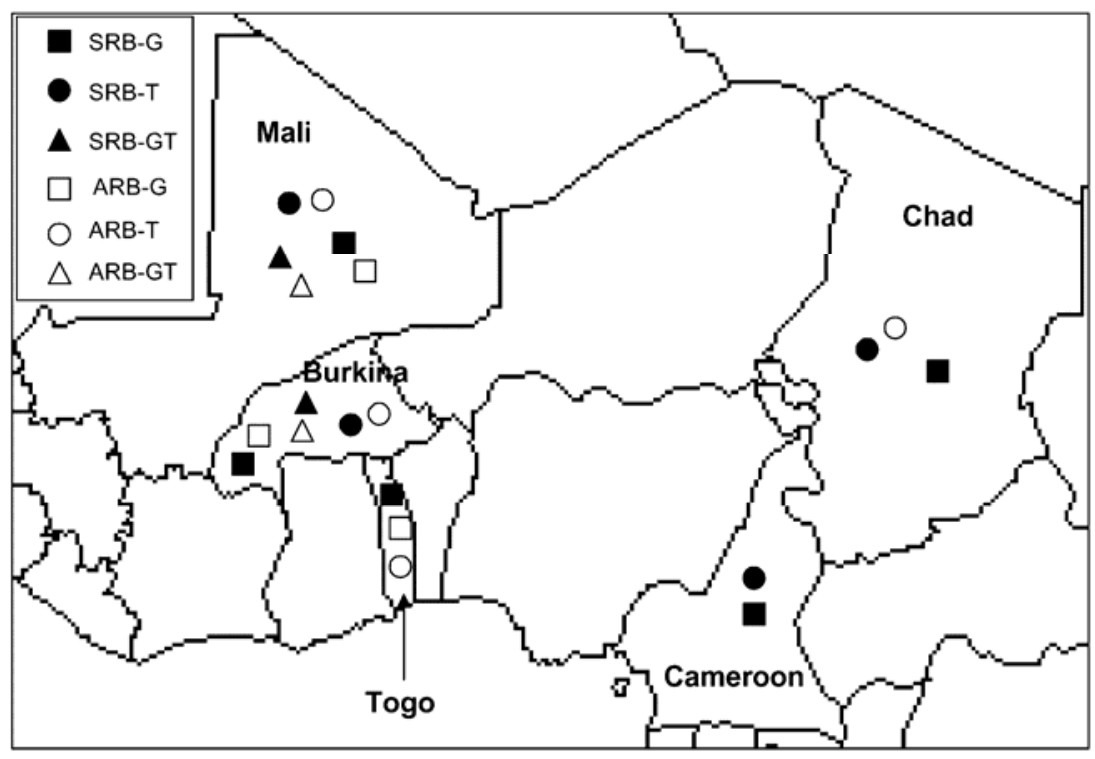

Fig. 2. Occurrence of resistance-breaking (RB) isolates of Rice yellow mottle virus (RYMV) in five countries of West and Central Africa. SRB and ARB are symptomatic and asymptomatic RB isolates, respectively. Resistance was broken down in rice cultivars Gigante (G) or Tog5681 (T) singly or in both cultivars simultaneously (GT).

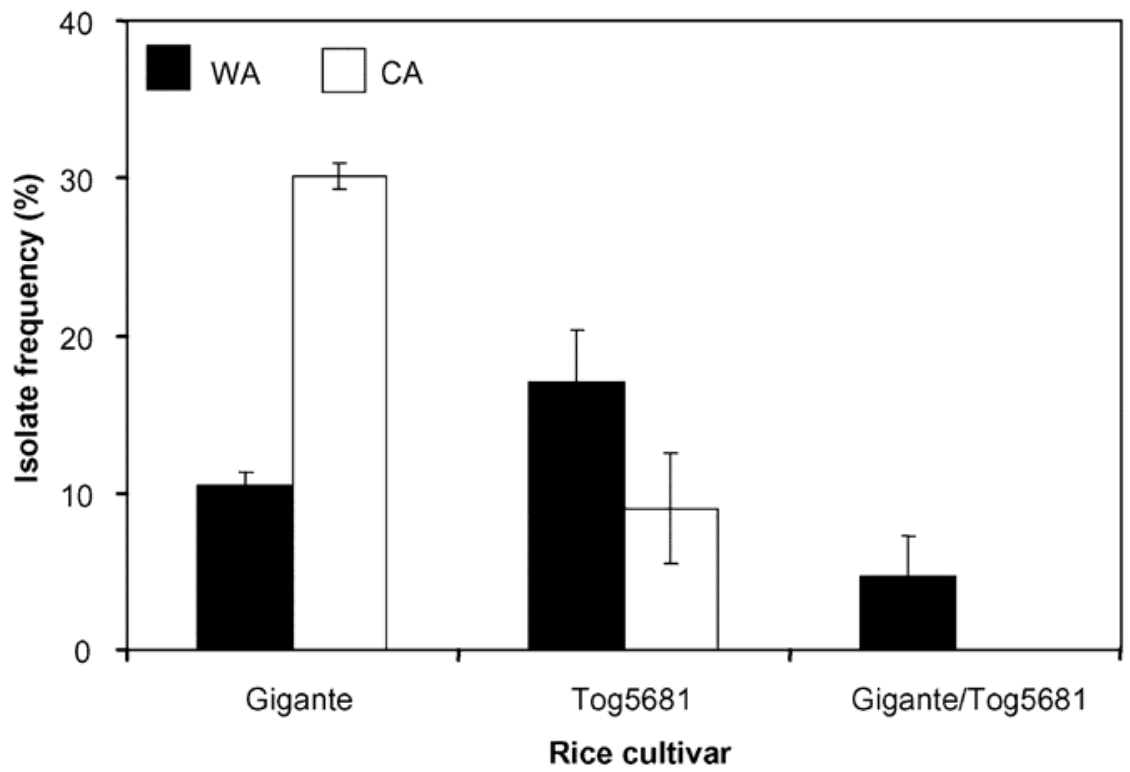

Fig. 3. Frequency of high resistance-breaking isolates of Rice yellow mottle virus in West (WA) and Central (CA) African regions. Errors bars represent standard errors of the means. 
of the two cultivars is controlled by the same gene (18). However, in some other respects, Gigante and Tog5681 exhibited noteworthy differences. In either population of the SRB or ARB isolates, Gigante was infected by some isolates that did not infect Tog5681 and vice versa, whereas other isolates were able to overcome the high resistance in the two cultivars. These discrepancies in responses of Gigante and Tog5681 to viral infection support the existence of at least two alleles of the gene controlling the high resistance to RYMV (9). Moreover, resistance in Gigante was broken down more often by SRB isolates than by ARB isolates, and the reverse situation was found in Tog5681. This particular difference may partly reflect the difficulty of discerning symptoms in Tog5681. Accordingly, some symptombearing plants might have been mistaken for asymptomatic ones and the corresponding inoculated virus isolates considered as ARB isolates in lieu of SRB isolates.

The RB isolates were widely distributed throughout the Sudano-savannah zone. RB isolates capable of overcoming the high resistance in Gigante or Tog5681 were surveyed. In West Africa, isolates overcoming the high resistance in Tog5681 were more frequent and symptoms were milder than in Gigante. These features may have resulted from a long co-evolution between RYMV isolates and ancestors of Tog5681 (O. glaberrima) which were doNiger (West Africa) (23). Most RYMV isolates of West African savannahs belong to the S1 strain $(2,22)$. Isolates of central African savannahs make a sister group of identified in each of the five countries mesticated in the inland delta area of the

the S1 strain of West Africa $(2,8,27,28)$. Both populations included isolates that could overcome the high resistance to RYMV. Either this trait occurred first in their common ancestor before the divergence of the two strains or, alternatively, the resistance-breaking ability appeared independently in already diverged populations. The second hypothesis is supported by recent phylogenetic analyses of West and Central African isolates of different pathotypes showing a lack of relationship between phylogeny and pathogenicity (26).

Some authors argued that resistance against pathogens may be considered broken if virulent isolates of those pathogens reach a detectable frequency (even as low as $1 \%$ ) in the population (17). About $40 \%$ of RB isolates were found in populations of RYMV in the Sudano-savannah zone. Consequently, high resistance to RYMV identified in rice cultivars Gigante and Tog5681 may be considered broken. Altogether, our results underline the potential high risk that may alter the effectiveness of the genetic control of rice yellow mottle based solely on the use of high resistance to RYMV. However, it cannot be stated from the presence of RB isolates only, that the high resistance to RYMV may not be used for a durable management of rice yellow mottle disease. Only isolates with scores equal to or higher than 5 directly induce losses in resistant cultivars. For other RB isolates, it should be tested whether they could evolve to more severe and damaging forms after inoculation to resistant cultivars. Efficient resistance breaking under field conditions will depend on parameters such as prevailing

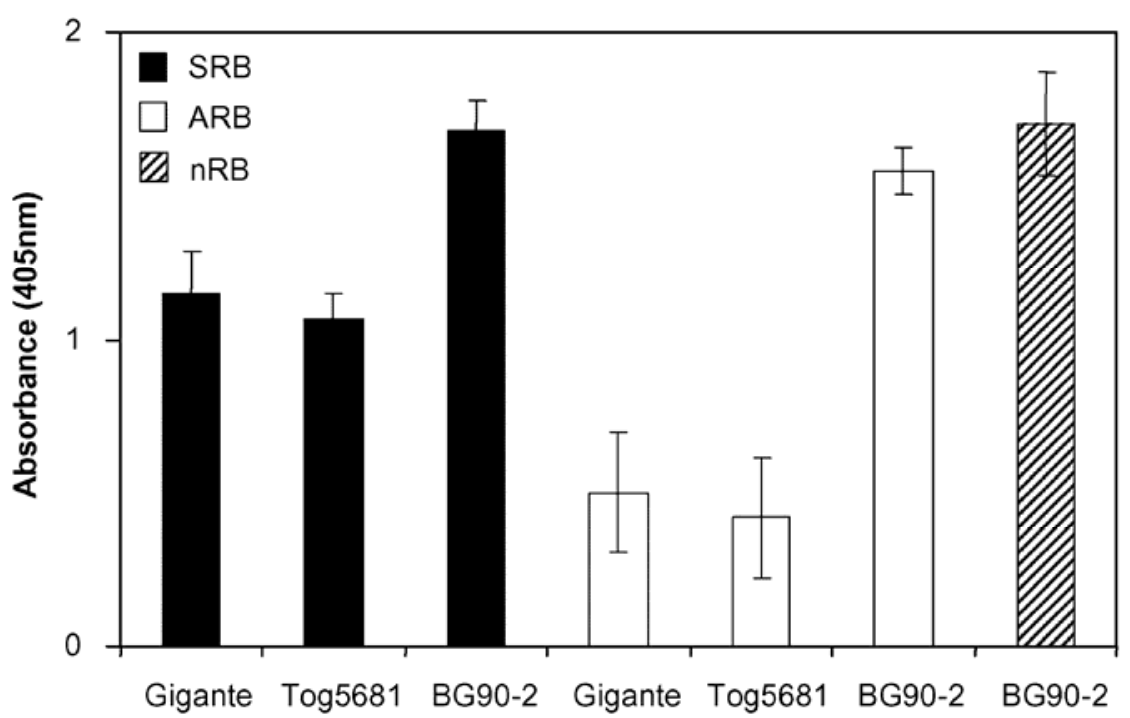

\section{Rice cultivar}

Fig. 4. Virus titers in highly resistant rice cultivars Gigante and Tog5681 infected by resistancebreaking (RB) isolates of Rice yellow mottle virus that induced symptoms (SRB) or did not induce any symptom (ARB). Virus titers in the susceptible cultivar BG90-2 infected by each type of isolate as well as by non-resistance-breaking isolates are shown for comparison. Errors bars represent standard errors of the means. ecological conditions or virus transmission mode $(11,26)$.

\section{ACKNOWLEDGMENTS}

We are grateful to J. Aribi for his skillful technical assistance. Research stays at Montpellier (France) for O. Traoré were financially supported by the Institut de Recherche pour le Developpement (IRD). This work was partially funded by the French Government through the "AIRE DEVELOPPEMENT" program.

\section{LITERATURE CITED}

1. Abo, M., Sy, A. A., and Alegbejo, M. 1998. Rice yellow mottle virus (RYMV) in Africa: Evolution, distribution, economic significance and sustainable rice production and management strategies. J. Sust. Agric. 11:85-111.

2. Abubakar, Z., Ali, F., Pinel, A., Traoré, O. N'Guessan, P., Notteghem, J. L., Kimmins, F. Konaté, G., and Fargette, D. 2003. Phylogeography of Rice yellow mottle virus in Africa. J. Gen. Virol. 84:733-743.

3. Awoderu, V. A. 1991. Rice yellow mottle virus in West Africa. Trop. Pest Manag. 37:356-362.

4. Bakker, W. 1970. Rice yellow mottle, a mechanically transmissible virus disease of rice in Kenya. Neth. J. Plant Pathol. 76:53-63.

5. Bakker, W. 1971. Three new beetle vectors of rice yellow mottle virus in Kenya. Neth. J. Plant Pathol. 77:201-206.

6. Clark, M. F., and Adams, R. N. 1977. Characteristics of microplate method of enzymelinked immunosorbent assay for detection of plant virus. J. Gen. Virol. 34:475-483.

7. Coulibaly, M. M., Konaté, G., and Zongo, J. D. 1999. Criblage variétal du riz pour la résistance au RYMV au Sahel. Rev. Cames. 1:7-13.

8. Fargette, D., Pinel, A., Abubakar, Z., Traoré, O., Brugidou, C., Sorho, F., Hébrard, E., Choisy, M., Séré, Y., Fauquet, C., and Konaté, G. 2004. Inferring the evolutionary history of Rice yellow mottle virus from genomic, phylogenetic, and phylogeographic studies. J. Virol. 78:3252-3261.

9. Fargette, D., Pinel, A., Traoré, O., Ghesquière, A., and Konaté, G. 2002. Emergence of resistance-breaking isolates of Rice yellow mottle virus during serial inoculations. Eur. J. Plant Pathol. 108:585-591.

10. Fleiss, J. L. 1981. Statistical Methods for Rates and Proportions. John Wiley \& Sons, New York.

11. García-Arenal, F., and McDonald, B. A. 2003. An analysis of the durability of resistance to plant viruses. Phytopathology 93:941-952.

12. Harrison, B. D. 2002. Virus variation in relation to resistance-breaking in plants. Euphytica 124:181-192.

13. Ioannidou, D., Lett, J., Pinel, A., Assigbetse, K., Brugidou, C., Ghesquière, A., Nicole, M., and Fargette, D. 2000. Responses of Oryza sativa japonica sub-species to infection with Rice yellow mottle virus. Physiol. Mol. Plant Pathol. 57:177-188.

14. John, V. T., and Thottappilly, G. 1987. A scoring system for rice yellow mottle virus. Int. Rice Res. Newsl. 12:26.

15. Konaté, G., Traoré, O., and Coulibaly, M. M. 1997. Characterization of rice yellow mottle virus isolates in Sudano-Sahelian areas. Arch. Virol. 142:1117-1124.

16. Kouassi, N. K., N'Guessan, P., Albar, L., Fauquet, C., and Brugidou, C. 2005. Distribution and characterization of Rice yellow mottle virus: A threat to African farmers. Plant Dis. 89:124-132.

17. McDonald, B. A., and Linde, C. 2002. The population genetics of plant pathogens and breeding strategies for durable resistance. Euphytica 124:163-180.

18. Ndjiondjop, M. N., Albar, L., Fargette, D. Fauquet, C., and Ghesquière, A. 1999. The ge- 
netic basis of high resistance to rice yellow mottle virus (RYMV) in cultivars of two cultivated rice species. Plant Dis. 83:931-935.

19. Ndjiondjop, M. N., Brugidou, C., Zang, S., Fargette, D., Ghesquière, A., and Fauquet, C. 2001. High resistance to Rice yellow mottle virus (RYMV) in two cultivated rice cultivars is correlated to the failure of cell-to-cell movement. Physiol. Mol. Plant Pathol. 59:309-316.

20. N'Guessan, P., Pinel, A., Caruana, M., Frutos, R., Sy, A., Ghesquiere, A., and Fargette, D. 2000. Evidence of the presence of two serotypes of rice yellow mottle sobemovirus in Côte d'Ivoire. Eur. J. Plant Pathol. 106:167178.

21. N'Guessan, P., Pinel, A., Sy, A. A., Ghesquière, A., and Fargette, D. 2001. Distribution, pathogenicity, and interactions of two strains of Rice yellow mottle virus in forested and sa- vannah zones of West Africa. Plant Dis. 85.5964.

22. Pinel, A., N'Guessan, P., Bousalem, M., and Fargette, D. 2000. Molecular variability of geographically distinct isolates of Rice yellow mottle virus in Africa. Arch. Virol. 145:16211638.

23. Porteres, R. 1950. Vielles agricultures de l'Afrique intertropicale. Agron. Trop. 5:489507.

24. Sarra, S., Oevering, P., and Peters, D. 2004. Wind-mediated spread of Rice yellow mottle virus (RYMV) in irrigated rice crops. Plant Pathol. 53:148-153.

25. Sarra, S., and Peters, D. 2003. Rice yellow mottle virus is transmitted by cows, donkeys, and grass rats in irrigated rice crops. Plant Dis. 87:804-808.

26. Sorho, F., Pinel, A., Traoré, O., Bersoult, A.,
Guesquière, A., Hébrard, E., Konaté, G., Séré, Y., and Fargette, D. 2005. Durability of natural and transgenic resistances in rice to Rice yellow mottle virus. Eur. J. Plant Pathol. 112:349359.

27. Traoré, O., Pinel, A., Fargette, D., and Konaté, G. 2001. First report and characterization of Rice yellow mottle virus in Central Africa. Plant Dis. 85:920.

28. Traoré, O., Sorho, F., Pinel, A., Abubakar, Z. Banwo, O., Maley, J., Hébrard, E., Winter, S. Séré, Y., Konaté, G., and Fargette, D. 2005. Processes of diversification and dispersion of Rice yellow mottle virus inferred from largescale and high-resolution phylogeographic studies. Mol. Ecol. 14:2097-2110.

29. West Africa Rice Development Association (WARDA/ADRAO). 2001. NERICA rice for life. WARDA/ADRAO, Bouaké. 